\title{
CONVEGNO INTERNAZIONALE DIRITTO ROMANO PRIVATO E DIRITTO ROMANO PUBBLICO: TEORIA E PRATICA. XIAMEN, CHINY, 23-27 PAŹDZIERNIKA 2010 R.
}

W dniach 23-27 października 2010 r. w Xiamen w południowochińskiej prowincji Fujian odbyło się Convegno internazionale Diritto romano privato e diritto romano pubblico: teoria e pratica. Językami konferencji były włoski, angielski i chiński, a dokładnie mandaryński.

Obrady rozpoczęły się 25 października. W poprzednich dniach, które miały być poświęcone na zwiedzanie, plany pokrzyżowało nadejście tajfunu.

Organizator konferencji, Profesor Xu Guodong z Uniwersytetu w Xiamen, otworzył obrady i przewodniczył pierwszej sesji. Pierwszy referat wygłosił Profesor Massimiliano Madio z Università di Bari, który mówił na temat podatków: Lo stipendium. Riflessioni di natura giuridica ed incertezze interpretative. Pani Profesor Maria Zabłocka z Uniwersytetu Warszawskiego przedstawiła refleksje dotyczące zasad prawa rzymskiego stanowiących podstawę nauki prawa: Il diritto romano - caposaldo teoretico della giurisprudenza. Następnie Profesor Jan Zabłocki z Uniwersytetu Kardynała Stefana Wyszyńskiego w Warszawie omówił problematykę aktów prawnych uchwalanych na zgromadzeniach: 'Leges' votate nelle assemblee popolari. Ostatni referat wygłosił Wang Yingying z Università di Macao na temat L'obbligazione 'in solidum' nelle 'actiones adiecticiae qualitatis' e la sua diffusione nei codici civili moderni del sistema romanistico. $\mathrm{W}$ dyskusji poruszano między innymi zagadnienia związane z przejściem od republiki do pryncypatu i zmianami podatkowymi, a także z walka plebejuszy o prawa polityczne.

Obradom w sesji porannej 26 października przewodniczyła Pani Profesor Maria Zabłocka. Referat na temat opieki i kurateli, The Enlightenment of Tutela and Cura in Roman Law to Modern Guardianship, wygłosiła Nina z Uniwersytetu w Xiamen. Chen Bangfeng mówił o marnotrawcach - The Prodigus of Roman Law: Rules and Principles. Profesor Xu Guodong wygłosił referat 'Parens 
patriae' in diritto romano. O małżeństwach cesarza Nerona mówiła dr Anna Tarwacka z Uniwersytetu Kardynała Stefana Wyszyńskiego w Warszawie: Le vicende matrimoniali di Nerone nella luce della legislazione di Augusto. Obrady podsumowane zostały w dyskusji.

Sesję popołudniową prowadził Profesor Jan Zabłocki. Chen Xiaoyuan z Uniwersytetu w Xiamen omówił adopcję: Adoptive Ideals Reflected in Requirements for Adoption in Roman Law-Reference to Gaius' Institutions, Justinian's Codex and Corpus iuris civilis digesta. Ruan Huiling z II Università di Roma 'Tor Vergata' zajęła się fundacjami dobroczynnymi: I fondi benefici nel diritto romano. Qi Yun z Uniwersytetu w Xiamen wygłosił referat Esegesi di D.45,1,72 pr. - Sul principio della divisibilità della compensazione dell' inadempimento delle obbligazioni indivisibili. Na koniec Huang Wenhuang przedstawił zagadnienie Hypothetical Causation in Tort Law: a Modern Perspective on Roman Problem, po czym nastapiła dyskusja.

Obradom 27 października przewodniczył Profesor Massimiliano Madio. Referat na temat Due categorie moderne e tre piani dei pensieri romani: il problema causale e astratto di trasferimento della proprietà wygłosił Lou Aihua z Uniwersytetu w Xiamen. Następnie Wang $\mathrm{Na}$ z Uniwersytetu w Xiamen mówiła o połączeniu w wystąpieniu zatytułowanym The Principal Thing and the Accessory Thing in Roman Law. Sesję zakończyła dyskusja. Całość obrad podsumował Profesor $\mathrm{Xu}$ Guodong wyrażając zadowolenie z przebiegu konferencji. Za trud włożony w organizację i przyjęcie gości wyrazili wdzięczność Massimiliano Madio i Maria Zabłocka. Profesor Jan Zabłocki zaproponował zorganizowanie kolejnego spotkania naukowego, zapraszając uczestników do Warszawy.

Uczestnicy mieli możliwość zwiedzenia przepięknej wyspy Gulangyu znanej jako Wyspa Fortepianów, buddyjskiej świątyni Nanputuo i ogrodu botanicznego, a także obserwowania ceremonii parzenia herbaty.

\footnotetext{
* Uniwersytet Kardynała Stefana Wyszyńskiego.
} 